International Journal of Economics, Business and Accounting Research (IJEBAR)

Peer Reviewed - International Journal

Vol-3, Issue-3, 2019 (IJEBAR)

E-ISSN: 2614-1280 P-ISSN 2622-4771

http://jurnal.stie-aas.ac.id/index.php/IJEBAR

\title{
EFFECT OF MANAGERIAL OWNERSHIP, DEBT COVENANT, POLITICAL COST AND GROWTH OPPORTUNITIES ON ACCOUNTING CONSERVATISM LEVELS
}

\author{
Chusnul Nuraeni ${ }^{1}$, Annafi Indra Tama ${ }^{2}$ \\ Islamic University of 45 Bekasi, Indonesia \\ Email: chusnul.nuraeni98@gmail.com
}

\begin{abstract}
The purpose of this study was to determine the effect of managerial ownership, debt covenants, political costs and growth opportunities on the level of accounting conservatism, case studies on manufacturing companies listed on the Indonesia Stock Exchange 2011-2015. Testing this hypothesis uses multiple regression analysis. The regression coefficient test ( $\mathrm{T}$ Test) in this study shows that the debt covenant and growth opportunities have a significant negative effect on the level of accounting conservatism, while the managerial ownership and political cost variables have no significant effect on the level of accounting conservatism. Suggestions for this study are to be able to expand the research sample so that the results can be generalized and can also be used to add or replace other variables that can affect accounting conservatism.
\end{abstract}

Keywords : Accounting Conservatism, Managerial Ownership, Debt Covenants, Political Cost, Growth Opportunities

\section{Introduction}

The use of the conservatism concept in managing financial statements aims to recognize, measure and report on the value of assets and low income or profit, and high value obligations and expenses. Specifically, this principle is preferred because it generates low profit and asset figures and costs and debt rates tend to be high (Fatmariani, 2013). As a result, financial statements will produce profits that are too low (understatement). Such a trend occurs because conservatism adheres to the principle of slowing down income recognition and accelerating recognition of costs. The implication of the application of this principle is the choice of accounting methods shown in methods that report lower profits and assets or higher debt (Nugroho and Indriana, 2012).

There are many factors that influence management to take conservative actions, including managerial ownership. Managerial ownership reflects the percentage of shares held by management from all the shares in the company. The bonus plan hypothesis states that managers will act in tandem with the bonuses given (Watts and Zimmerman, 1986). If the company's profit target is reached, then the bonus will be given to management by the owner. That way, company reporting will be less conservative because it will bring benefits in the form of bonuses given to management. 
International Journal of Economics, Business and Accounting Research (IJEBAR)

Peer Reviewed - International Journal

Vol-3, Issue-3, 2019 (IJEBAR)

E-ISSN: 2614-1280 P-ISSN 2622-4771

http://jurnal.stie-aas.ac.id/index.php/IJEBAR

2. Theoritical Review

2.1 Agency Theory

Agency theory is a theory that arises because of a conflict of interest between the principal and the agent. Principal as shareholder while agent as manager. Principals contract agents to manage resources within the company. The main purpose of agency theory is to explain how contracting parties can design contracts whose purpose is to minimize costs as a result of asymmetrical information (Main, 2015).

\subsection{Positive Accounting Theory}

Positive accounting theory was formulated by Watss and Zimmerman, 1986. Positive Accounting Theory adheres to the notion of maximizing wealth and individual interests. There are three hypotheses in this theory that can explain management decisions to act conservatively or not.

The hypothesis bonus plan, states that managers act along with the bonuses given. If the company's profit target is achieved, then the bonus will be given to company management.

The Debt covenant hypothesis predicts that managers want to increase profits and assets to reduce the cost of renegotiating debt contracts when the company decides on its debt agreement.

The level of conservatism in earnings reporting based on the debt covenant hypothesis can be explained by the debt / asset hypothesis which is a limitation of debt covenants. This debt / asset hypothesis can be explained using leverage ratio which is the ratio between debt and total assets. In the political cost hypothesis, large companies are predicted to be more sensitive to the existence of political costs than small companies (Watts and Zimmerman, 1986). Political costs themselves arise from conflicts of interest between managers and the government, where companies are considered to be responsible for the social interests of the community.

\subsection{Accounting Conservatism}

According to Soewardjono (2011) Conservatism is an attitude or flow in the face of uncertainty to take actions or decisions on the basis of the ugliest emergence of these uncertainties. Beaver and Ryan (2000) in Watts (2003) also classify conservatism or bias as a persistent difference between market value and book value, distinguished from temporal differences such as economic gains and losses which are recognized in book values gradually over time.

\subsection{Managerial Ownership}

According to Ratna (2008) managerial ownership is the number of shares of public companies owned by individuals or elite groups originating from within companies that have a direct interest in the company.

\subsection{Debt Covenant}

Debt covenant is a contract aimed at borrowers by creditors to limit activities that might damage the value of loans and loan recovery (Cochran, 2001 in Fatmariani, 2013). To identify debt covenants is to use a proxy of the level of leverage (Oktomegah, 2012). A comparison between debt and assets that shows several parts of assets used to guarantee debt or commonly referred to as leverage is a measure related to the existence of a debt agreement. Creditors have claims / 
International Journal of Economics, Business and Accounting Research (IJEBAR)

Peer Reviewed - International Journal

Vol-3, Issue-3, 2019 (IJEBAR)

E-ISSN: 2614-1280 P-ISSN 2622-4771

http://jurnal.stie-aas.ac.id/index.php/IJEBAR

interests in company assets and the greater the company's debt, the greater the creditor's claims to the company's assets.

\subsection{Political Cost}

Political costs cover all wealth transfer costs that must be borne by the company in relation to antitrust actions, regulations, government subsidies, taxes, tariffs, labor demands and others (Almilia, 2007). If large companies have relatively permanent high profits, then the government can be encouraged to raise taxes and request higher public services to the company. Finally, managers of large companies may be inclined to choose accounting methods that delay earnings reporting to reduce the cost of political costs by the company (Reskino and Vemiliyarni, 2014).

\subsection{Growth Opportunities}

Growth Opportunities are opportunities for companies to invest in profitable things (Astarini, 2011). The company's growth can be seen from growth opportunities. In addition to growth opportunities, companies also need funds where there are challenges for managers to balance the income and use of debt needed by the company. The higher the chance of growing the company, the greater the funding needs of the company.

\section{Research Metodology}

\subsection{The scope of research}

This research is associative research and uses a quantitative approach. Associative research is research that aims to determine the influence of two or more variables (Sugiyono, 2011). This study aims to examine the effect of independent variables namely managerial ownership, debt covenant, political cost and growth opportunities on the dependent variable in this study is the level of accounting conservatism.

\subsection{Data Analysis Techniques}

The data analysis technique in this study uses statistical calculations, namely multiple regression. After the data needed in this study are collected, then the next data analysis is carried out consisting of descriptive statistical analysis, classic assumption test and hypothesis test.

\section{Research Findings}

4.1 Effect of Managerial Ownership on the Level of Accounting Conservatism.

In this study it can be concluded that managerial share ownership is not a factor that influences companies to apply accounting conservatism. Influence between management ownership owned by accounting and accounting conservatism is because in descriptive statistics the number of average shares held by managers in companies in Indonesia is relatively small with an average of $5.68 \%$. This proves that the majority of companies in Indonesia are mostly owned by external companies and have an impact on the strong control of the company by majority shareholders. So, the existence of managerial share ownership in the company does not affect the company's policies too much, including determining the level of corporate conservatism. 
International Journal of Economics, Business and Accounting Research (IJEBAR)

Peer Reviewed - International Journal

Vol-3, Issue-3, 2019 (IJEBAR)

E-ISSN: 2614-1280 P-ISSN 2622-4771

http://jurnal.stie-aas.ac.id/index.php/IJEBAR

4.2 Effect of Covenant Debt on the Level of Accounting Conservatism.

The results of this study indicate that debt covenants have a significant negative effect on the level of accounting conservatism.

This is in accordance with the debt covenant hypothesis in positive accounting theory which states that debt covenants have a negative effect on accounting conservatism. This proves that the company will always want to show good performance towards creditors, namely by conducting financial reporting optimistically or less conservatively. This is done by the company to get long-term debt from the creditor and the creditor can be sure that the funds they provide will be guaranteed.

\subsection{Effect of Political Cost on the Level of Accounting Conservatism.}

The findings of this study indicate that political costs do not significantly influence the level of accounting conservatism.

This is not in accordance with the political cost hypothesis in positive accounting theory which states that large-sized companies that have large political costs will also apply the principle of accounting conservatism to reduce their political costs. Based on the results of this study it can be concluded that the company does not consider its size too much in making more conservative decisions. Almilia (2007) states that small companies also tend to receive a considerable impact from regulations set by the government or in other words small-sized companies are very vulnerable because of political costs, therefore small companies are more likely to be conservative than large companies.

\subsection{Effect of Growth Opportunities on the Level of Accounting Conservatism.}

Growth opportunities have a significant negative effect on the level of accounting conservatism. Based on this study it was concluded that companies that have a high growth opportunity tend not to use conservatism methods for reporting. This is because a growing company already has good corporate governance, making it less likely to apply the principle of conservatism by minimizing profits to meet the investment funds needed by the company in its growth. Companies with high growth opportunities will indeed need sufficient amounts of funds to finance their future growth.

\section{Conclusion}

Managerial ownership does not have a significant effect on the level of accounting conservatism. These results are not in line with the bonus plan hypothesis which states that managerial ownership has a positive effect on accounting conservatism. While Debt covenant has a significant negative effect on the level of accounting conservatism. This result is in accordance with the debt covenant hypothesis which states that debt covenants have a negative effect on the level of accounting conservatism. The Political cost does not have a significant effect on the level of accounting conservatism. These results are not in accordance with the political cost hyphotesis which states that political costs have a positive effect and Growth opportunities have a significant negative effect on the level of accounting conservatism. 
International Journal of Economics, Business and Accounting Research (IJEBAR)

Peer Reviewed - International Journal

Vol-3, Issue-3, 2019 (IJEBAR)

E-ISSN: 2614-1280 P-ISSN 2622-4771

http://jurnal.stie-aas.ac.id/index.php/IJEBAR

\section{Bibliography}

Agustina, dkk. 2016. "Analisis Faktor-Faktor yang Mempengaruhi Penerapan Konservatisme Akuntansi pada Perusahaan Manufaktur yang Terdaftar di Bursa Efek Indonesia”. Jurnal Dinamika Akuntansi dan Bisnis vol.3(1),pp 1-16. Diakses: 2 Januari 2017.

Alfian, Angga dan Arifin Sabeni. 2013. "Analisis Faktor-Faktor yang Berpengaruh terhadap Pemilihan Konservatisme Akuntansi”, Journal of Accounting Vol. 2 No.3, halaman 1-10. Diakses : 5 Maret 2017

Alhayati, Fajri. 2013. "Pengaruh Tingkat Hutang (Leverage) dan Tingkat Kesulitan Keuangan Perusahaan terhadap Konservatisme Akuntansi (Studi Empiris Pada Perusahaan Yang Terdaftar di PT BEI)", Artikel Penelitian Fakultas Ekonomi Universitas Negeri Padang.

Almilia, Luciana Spica. 2007. "Pengujian Size Hypotesis dan Debt/Equity Hypotesis yang Mempengaruhi Tingkat Konservatisma Laporan Keuangan Perusahaan dengan Teknik Analisis Multinomial Logit”. Jurnal Bisnis dan Akuntansi. Halaman 1-23

Anggraini, Fivi dan Ira Trisnawati. 2008. "Pengaruh Earning Management terhadap Konservatisme Akuntansi”, Jurnal Bisnis dan Akuntansi vol.10, No.1, pp 1-14. Diakses 10 Januari 2017.

Ardina, Ayu Martaning Yogi dan Indira Januarti. 2012. "Penggunaan Perspective Positive Accounting Theory Terhadap Konservatisme Akutansi di Indonesia”. Diponegoro Journal Of Accounting. Universitas Diponegoro.

Astarini, Dwi. 2011. "Analisis Faktor-Faktor Yang Mempengaruhi Pilihan Perusahaan Terhadap Konservatisme Akuntansi”. Skripsi. Jakarta : Universitas Pembangunan Nasional Veteran.

Brilianti, Dinny Prastiwi. 2013. "Pengaruh Kepemilikan Manajerial, Kepemilikan Institusional, Leverage, dan Komite Audit terhadap Konservatisme Akuntansi”. Skripsi. Semarang : Universitas Negeri Semarang.

Dewi, Ni Kd Sri Lestari dan I Ketut Suryanawa. 2013. "Pengaruh Struktur Kepemilikan Manajerial, Leverage dan Financial Distress terhadap Konservatisme Akuntansi”. EJournal Akuntansi Universitas Udayana, Vol.7 No.1.2014.

Deslatu, Shella dan Yulius Kurnia Susanto. 2009. "Pengaruh Kepemilikan Manajerial, Debt Covenant, Litigation, Tax and Political Cost dan Kesempatan Bertumbuh terhadap Konservatisme Akuntansi”. Jakarta. STIE Trisakti Jakarta.

Fala, Dwi Yana Amalia. 2007. "Pengaruh Konservatisme Akuntansi terhadap Penilaian Ekuitas Perusahaan dimoderasi oleh Good Corporate Governance”. Simposium Nasional Akuntansi X Makasar.

Fatmariani. 2013. "Pengaruh Struktur Kepemilikan, Debt Covenant, dan Growth Opportunities terhadap Konservatisme Akuntansi pada Perusahaan Manufaktur yang Terdaftar di BEI’.Skripsi. Padang: Universitas Negeri Padang

Ghozali, Imam. 2013. "Aplikasi Analisis Multivariate Dengan Program Edisi Ketujuh”. Semarang : Badan Penerbit Universitas Diponegoro.

Givoly, Dan dan Carla Hayn. 2002. " The Changing Time-Series Properties of Earnings, Cash Flows and Accrual : Has Financial Reporting Become More Conservative? "Journal of Accounting and Economic. 287-320.

Lasdi, Lodovicus. 2009. "Pengujian Determinan Konservatisme Akuntansi”. Jurnal Akuntansi Kontemporer, vol.1 no.1, halaman 1-20. 
International Journal of Economics, Business and Accounting Research (IJEBAR)

Peer Reviewed - International Journal

Vol-3, Issue-3, 2019 (IJEBAR)

E-ISSN: 2614-1280 P-ISSN 2622-4771

http://jurnal.stie-aas.ac.id/index.php/IJEBAR

Mayangsari, Sekar dan Wilopo. 2002. "Konservatisme Akuntansi, Value Relevance dan Discretionary Accruals : Implikasi Empiris Model Feltham Ohlson (1996)”, Simposium Nasional Akuntansi : 685-708

Nugroho, Okta Dwi dan Dian Indriana T.L. 2012. "Faktor-Faktor yang Mempengaruhi Konservatisme Akuntansi (Studi Empiris Perusahaan Manufaktur di BEI tahun 20072009)". JURAKSI Vol.1 No.2. halaman 1-18

Oktomegah, Calvin. 2012. "Faktor-Faktor yang Mempengaruhi Penerapan Konservatisme pada Perusahaan Manufaktur di BEI”. Jurnal Ilmiah Mahasiswa Akuntansi-vol.1, no.1, halaman 1-7.

Rahardja, Natalia dan Amelia Sandra. 2014. "Pengaruh Insentif Pajak dan Faktor Non Pajak terhadap Konservatisme Akuntansi”. Prosiding Simpoium Nasional Perpajakan. Institut Bisnis dan Informatika Kwik Kian Gie.

Reskino dan Ressy Vemiliyarni. 2014. "Pengaruh Konvergensi IFRS, Bonus Plan, Debt Covenant dan Political Cost Terhadap Konservatisme Akuntansi”. Jakarta. UIN Syarief Hidayatullah.

Sari, Cynthia dan Desi Adhariani. 2009. "Konservatisme Akuntansi dan Faktor-faktor Yang Mempengaruhinya”. Simposium Nasional Akuntansi XII. Palembang.

Scott, William R. 2000. "Financial Accounting Theory”. Second Edition. Canada : Prentice Hall.

Septian, Ardo dan Yane Devi Anna. 2014. "Pengaruh Kepemilikan Manajerial, Ukuran Perusahaan, Debt Covenant dan Growth Opportunities terhadap Konservatisme Akuntansi". Journal Universitas Telkom Bandung. Halaman 1-18

Sugiono. 2011. Metode Penelitian Kuantitatif, Kualitatif dan R\&D. Bandung : Alfabeta.

Sukriya, Dewi. 2011. "Analisis Pilihan Perusahaan terhadap Akuntansi Konservatif (Studi Empiris pada Perusahaan Manufaktur di Bursa Efek Indonesia). Skripsi. Jember : Universitas Jember.

Sumiari, Kadek Nita dan Dewa Gede Wirama. 2016. "Pengaruh Ukuran Perusahaan Terhadap Konservatisme Akuntansi Dengan Leverage Sebagai Variabel Pemoderasi”. E-Jurnal Ekonomi dan Bisnis Universitas Udayana. Halaman 1-28.

Suwardjono. 2011. "Teori Akuntansi Perekayasaan Pelaporan Keuangan Edisi Ketiga Cetakan Kelima. Yogyakarta : BPFE Yogyakarta.

Utama, Ikhsan Yoga. 2015. "Pengaruh Struktur Kepemilikan Manajerial, Leverage, Growth Opportunties dan Ukuran Perusahaan terhadap Konservatisme Akuntansi (Studi pada Perusahaan Farmasi yang terdaftar di BEI 2010-2014)”. Skripsi. Jakarta : Universitas Islam Negeri Syarif Hidayatullah.

Wahyudiyati, Nur. 2010. "Pengaruh Kepemilikan Manajerial, Investment Opportunity Set (IOS) dan Price to Book Ratio terhadap Konservatisme Akuntansi. Skripsi. Surakarta : Universitas Sebelas Maret

Wardhani, Ratna. 2008. " Tingkat Konservatisme Akuntansi di Indonesia dan Hubungannya dengan Karakteristik Dewan Sebagai Salah Satu Mekanisme Corporate Governance”. Makalah SNA XI, Pontianak.

Watts, R. L. and J.L. Zimmerman. 1986. "Towards a Positive Theory of the Determination of Accounting Standards”. The Accounting Review. 53(1), 112-137. 
International Journal of Economics, Business and Accounting Research (IJEBAR)

Peer Reviewed - International Journal

Vol-3, Issue-3, 2019 (IJEBAR)

E-ISSN: 2614-1280 P-ISSN 2622-4771

http://jurnal.stie-aas.ac.id/index.php/IJEBAR

Watss,R. 2003. “Conservatism in Accounting Part I: Explanations and Implications.” Accounting Horizons vol.17 no.3. 207-221..

Watts, R. 2003. "Conservatism in Accounting Part II: Evidence and Research Opportunities: Accounting Horizons 17, halaman 287-301.

Wicaksono, Windra Septian. 2012. "Uji Empiris Faktor-Faktor Konservatisme Akuntansi Dalam Perpajakan”. Skripsi. Semarang : Universitas Diponegoro.

Widya. 2005. "Analisis Faktor-Faktor yang Mempengaruhi Pilihan Perusahan Terhadap Konservatisme Akuntansi”. Skripsi. Semarang : Universitas Diponegoro.

Wulansari, Cahya Agustin. 2014. "Pengaruh Struktur Kepemilikan, Kontrak Hutang dan Kesempatan Bertumbuh Pada Konservatisme Akuntansi." Jurnal Ilmu dan Riset Akuntansi Vol.3 No.8. halaman 1-18 